УДК 53.082.743

\title{
Technological Features Influence on Magnetic Sensitivity of Sensor Based on Ferromagnetic Structures
}

\author{
Nikolay A. Djuzhev \\ Aleksey S. Iurov \\ Nikita S. Mazurkin \\ Maksim Y. Chinenkov* \\ National Research University of Electronic Technology (MIET) \\ Shokina, 1, Moscow, Zelenograd, 124498
}

Russia

Received 20.08.2016, received in revised form 10.10.2016, accepted 04.02.2017

\begin{abstract}
Main urgent problems of the magnetic devices and primary converters development based on the magnetoresistive structures are the sensitivity improvement and thermal stability. The sensitivity was determined as the ratio of the magnitude of the output signal (imbalance voltage of the bridge under the action of magnetic field) to the magnetic field magnitude on the linear range of transfer characteristic. The investigated structures had a wide range of sensitivity values from $3.0(\mathrm{mV} / \mathrm{V}) /(\mathrm{kA} / \mathrm{m})$ to $9.4(\mathrm{mV} / \mathrm{V}) /(\mathrm{kA} / \mathrm{m})$, in the bias field value of $1 \mathrm{kA} / \mathrm{m}$. It is established what the main influence on the sensitivity of the sensor has a width of permalloy strips. The distance between the barber pole has a substantially smaller effect.
\end{abstract}

Keywords: magnetoresistive sensor, MEMS, magnetoresistance, magnetoresistor. DOI: $10.17516 / 1997-1397-2017-10-2-181-185$.

Creation of magnetic field sensor based on the anisotropic magnetoresistive transducer involves increasing the sensitivity and increase the thermal stability. The sensitivity to the magnetic field, which is determined by the ratio of the signal amplitude imbalance in magnetoresistive bridge caused the by influence of the magnetic field to the value of that field in the linear region of the transfer characteristics of the sensor [1-2] is the most important parameter, because it determines the use of sensors to address various problems. The range of use of magnetoresistive sensors in the technique is extremely wide therefore requirements to sensitivity value are extremely broad. The sensitivity value is influenced by a number of factors, among which first and foremost design and technology. Sensors based on magnetoresistive structures usually consist of a thin strip of magnetic material with thickness $0.03 \mu \mathrm{m}$, mainly iron-nickel alloy on which strips of high conductivity material (aluminum) are applied at an angle of $45^{\circ}$ [3]. These sensors are characterized by odd transfer characteristic with a sufficiently large linear range [4]. Studies conducted on various structures have shown that the greatest effect on the sensitivity has width (W) of the magnetic stripe and the distance between shunt strips (a) (Fig. 1, Tab. 1).

The graph in Fig. 2(a) shows that the characteristic of structures with strip width $40 \mu \mathrm{m}$ and a distance of $6 \mu \mathrm{m}$ and $10 \mu \mathrm{m}$ has greater sensitivity $(1.9 \mathrm{mV} / \mathrm{V} / \mathrm{Oe})$ relative to the structure with strip width of $10 \mu \mathrm{m}$ and same a distance $(0.78 \mathrm{mV} / \mathrm{V} / \mathrm{E})$. However, the use of topologies with wide magnetic stripe $30 \mu \mathrm{m}$ and more difficult due to reduction of the bridge

\footnotetext{
*chinenkov@inbox.ru

(c) Siberian Federal University. All rights reserved
} 


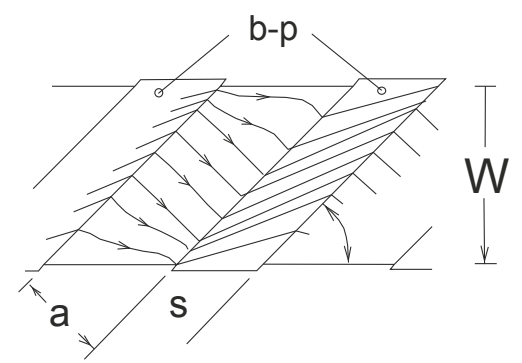

Fig. 1. General view of the strip of magnetic material with aluminum strips shunt [1]

Table 1. Values of sensitivity $(\mathrm{mV} / \mathrm{V} / \mathrm{Oe})$ for different width $\mathrm{W}$ of the magnetic strip and a distance between strips in a field shunt bias 12.5 Oe

\begin{tabular}{|c|c|c|c|}
\cline { 2 - 4 } \multicolumn{1}{c|}{} & \multicolumn{3}{c|}{$\mathrm{a}, \mu \mathrm{m}$} \\
\hline $\mathrm{W}, \mu \mathrm{m}$ & 6 & 10 & 15 \\
\hline 10 & - & 0.30 & 0.25 \\
\hline 30 & - & 0.64 & 0.62 \\
\hline 40 & 0.75 & 0.75 & 0.70 \\
\hline
\end{tabular}

circuit resistance, as can be seen from Tab. 2. AMR sensors with a resistance of bridge diagonal is less than $1 \mathrm{kOhm}$ consume more current for the same power supply voltage, and they dissipate more power, which leads to overheating of the device and the deterioration of the temperature characteristics. Resistance of bridge diagonal can be raised by increase of the length of magnetic strips, but this leads to undesirable increase of AMR transducer area.

Table 2. Values of resistance of bridge diagonal [kOhm] for the different widths of the magnetic strip $\mathrm{W}$ and the a distance between shunt strips at bias field of 12.5 Oe

\begin{tabular}{|c|c|c|c|}
\cline { 2 - 4 } \multicolumn{1}{c|}{} & \multicolumn{3}{c|}{$\mathrm{a}, \mu \mathrm{m}$} \\
\hline $\mathrm{W}, \mu \mathrm{m}$ & 6 & 10 & 15 \\
\hline 10 & - & 7.2 & 9.5 \\
\hline 30 & - & 0.72 & 0.8 \\
\hline 40 & 0.38 & 0.42 & 0.5 \\
\hline
\end{tabular}

These results show that the change in the distance between shunt strips has substantially lesser effect on the sensitivity of AMR sensors. Measurements were made at different values of the magnetizing field; results are shown in Fig. 2(b). Measurements indicate that for the same converter, initially having a sensitivity of $0.78(\mathrm{mV} / \mathrm{V}) /$ Oe in the magnetization field of $12.5 \mathrm{Oe}$, the sensitivity of $1.90(\mathrm{mV} / \mathrm{V}) /$ Oe can be achieved with a decrease in the magnetizing field to 1.2 A. In other words, the sensitivity of the structure with the same topology (geometry) can be changed within wide limits by using the. An important fact is that even with magnetizing field 4 Oe, hysteresis does not exceed 1\%. From Fig. 1 and Tab. 1 it follows that with an increase in the width of the magnetic strip increases the sensitivity of the AMP converter. The most likely explanation for this effect may be reducing of the influence of edge effects, which 


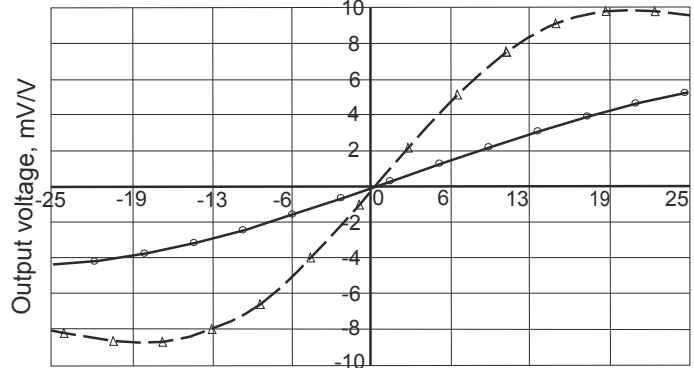

a)

Magnetic field, Oe

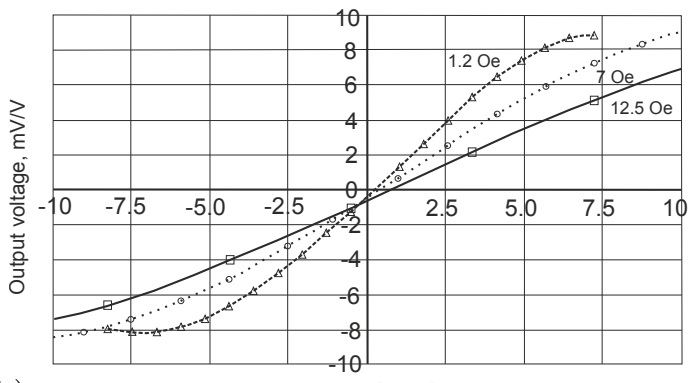

b)

Fig. 2. (a) Transfer characteristic: solid line is the sensitivity of $0.78(\mathrm{mV} / \mathrm{V}) /$ Oe $(\mathrm{W}=10$ $\mu \mathrm{m}, \mathrm{a}=15 \mu \mathrm{m}, \mathrm{s}=6 \mu \mathrm{m})$; dotted line is 1.90 Sensitivity $(\mathrm{mV} / \mathrm{V}) /$ Oe $(\mathrm{W}=40 \mu \mathrm{m}, \mathrm{a}=6 \mu \mathrm{m}$, $\mathrm{s}=6 \mu \mathrm{m}$ ). (b) Transmitting characteristic of the converter depending on the magnetizing field: solid line is the sensitivity of $0.8(\mathrm{mV} / \mathrm{V}) / \mathrm{Oe}$; dotted line is the sensitivity of $1.2(\mathrm{mV} / \mathrm{V}) /$ Oe; dashed line is the sensitivity of $1.9(\mathrm{mV} / \mathrm{V}) / \mathrm{Oe})$

appears to change the distribution of the current lines near the edges of the magnetic strip and, consequently, the change in the angle between the magnetization and current. Therefore, to reduce the influence of edge effects it is necessary either to change the distribution of the current lines by changing the geometry of shunt strips, or change the magnetization distribution. In this paper we have chosen change in the magnetization distribution in the magnetic strip by changing its geometry. Topology of the magnetic stripe, which is a magnetic layer with a shunt configuration repeating stripes of conductive layer is self-aligned structure [5], was developed as shown in Fig. 3(a).

a)

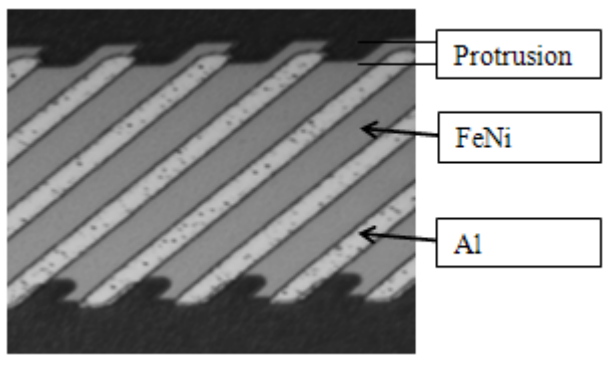

b)

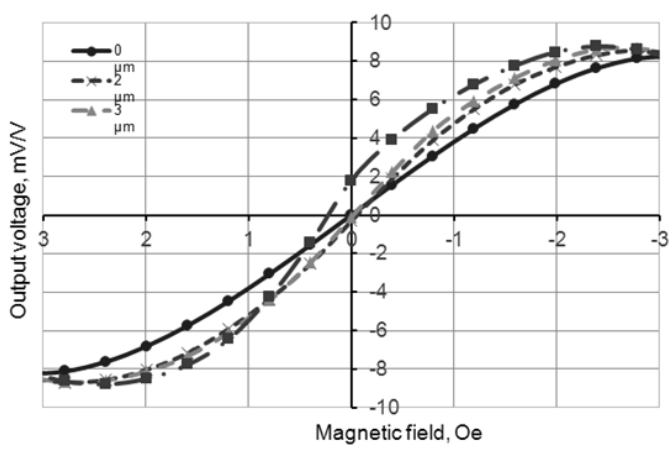

Fig. 3. (a) The plot of the self-aligned structure. (b) Mathematical simulation of AMR converter with self-aligned structure

Mathematical Simulation in COMSOL Multiphysics software package shown (Fig. 3(b)) that with using a self-aligned structure the sensitivity of AMR converter increases without changing other geometric dimensions. Fig. 3(b) and Tab. 1 show that there is an optimum size of the protrusion height $(3 \mu \mathrm{m})$, which allows to maximize the sensitivity and prevent the occurrence of hysteresis $(6 \mu \mathrm{m})$. To confirm the results of the simulation a test batch AMR converters with self-combined structure was made, Fig. 4(a). The measurement results have confirmed an 
in-crease in sensitivity while maintaining the geometric dimensions (Fig. 4(b)). AMR effect in permalloy film in the produced batch was $2.5 \%$. The coercive force and anisotropy field reached 1.8 Oe and 5 Oe, respectively.

a)

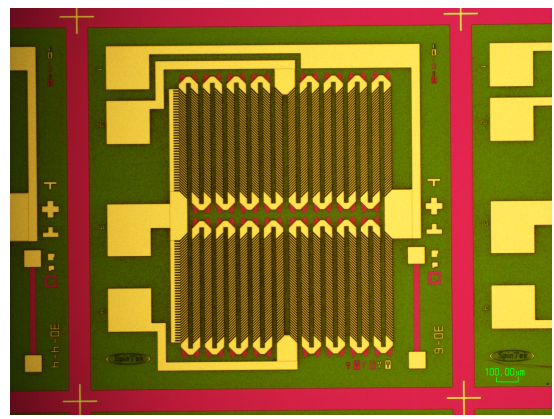

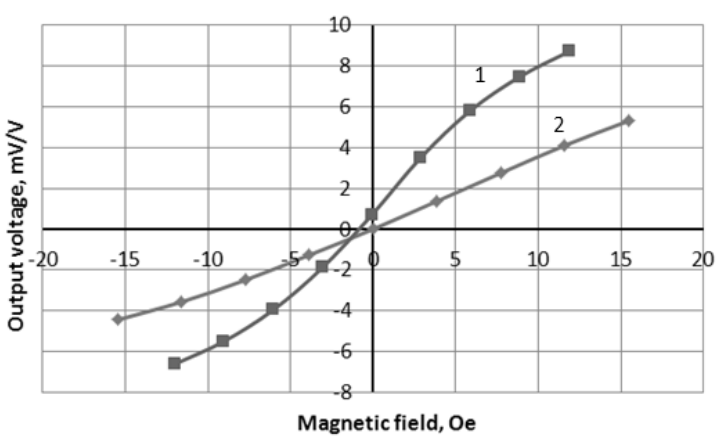

b)

Magnetic field, $\mathrm{Oe}$

Fig. 4. (a) General view self-aligned structures. (b) The transfer characteristic of self-aligned (1) and classical (2) structures with the magnetizing field $1 \mathrm{kA} / \mathrm{m}$

It should be mentioned that this effect is lower for structures with wider magnetic stripe (Tab. 3). This proves the assumption that the use of self-combined structure changes the magnetization on the edge of the magnetic stripe so that the reduced edge effects. Developed self-aligned structure showed a significant, more than 2.5 times increase in sensitivity to the structure with a width of the magnetic strip $10 \mu \mathrm{m}$ (Fig. 4(a)). This suggests that it is possible to reduce drastically the geometric size of the sensor, first of all its area, without changing its resistance. The sensitivity was determined as the ratio of the magnitude of the output signal (imbalance voltage of the bridge under the action of magnetic field) to the magnetic field magnitude on the linear range of transfer characteristic. The investigated structures had a wide range of sensitivity values from $3.0(\mathrm{mV} / \mathrm{V}) /(\mathrm{kA} / \mathrm{m})$ to $9.4(\mathrm{mV} / \mathrm{V}) /(\mathrm{kA} / \mathrm{m})$, in the bias field value of $1 \mathrm{kA} / \mathrm{m}$. It is established what the main influence on the sensitivity of the sensor has a width of permalloy strips. The distance between the barber pole has a substantially smaller effect.

Table 3. Change of AMR converters sensitivity with different widths of the magnetic strip with self-aligned topology

\begin{tabular}{|l|l|l|}
\hline $\begin{array}{l}\text { width of the magnetic } \\
\text { strip, } \mu \mathrm{m}\end{array}$ & $\begin{array}{l}\text { sensitivity of self-aligned } \\
\text { structure }, \mathrm{mV} / \mathrm{V} / \mathrm{Oe}\end{array}$ & $\begin{array}{l}\text { sensitivity of classic } \\
\text { structure, } \mathrm{mV} / \mathrm{V} / \mathrm{Oe}\end{array}$ \\
\hline 10 & 9.0 & 3.6 \\
\hline 30 & 10.3 & 7.9 \\
\hline
\end{tabular}

This work was supported by Ministry of Education and Science of the Russian Federation grant no. 14.578.21.0001 (RFMEFI57814X0001). and conducted using the equipment of Multiaccess center "Microsystem technics and electronics component base" MIET.

\section{References}

[1] U.Dibbern, Magnetoresistive sensors, Sensors, 5(1989), 341. 
[2] S.Tumanski, Thin film magnetoresistive sensors, CRC Press, 5(2001), 83.

[3] N.Wakatsuki, S.Kurashima, N.Shimizu, M.Endoh, A.Tanaka, Barber-pole magnetoresistive magnetic field sensor, United States Patent, 5, 055, 786, 1991.

[4] P.Chowdhury, Development of magne-toresistive thin film sensor for magnetic field sensing applications, Proceedings of the 57th DAE Solid State Physics Symposium, 2012.

[5] N.Dyuzhev, A.Yurov, R.Preobrazhenskii, N.Mazurkin, M.Chinenkov, Shape-Coupled Magnetoresistive Structures: a New Approach to Higher Sensitivity, Technical Physics Letters, 42 (2012), no. 5, 546-549.

\title{
Влияние технологических особенностей на чувствительность сенсоров на основе ферромагнитных структур
}

\author{
Николай А. Дюжев \\ Алексей С. Юров \\ Никита С. Мазуркин \\ Максим Ю. Чиненков
}

Национальный исследовательский университет электронных технологий (МИЭТ)

Шокина, 1, Москва, Зеленоград, 124498

Россия

\begin{abstract}
Основными актуальными задачами в разработке первичных преобразователей на основе магниторезистивных структур являются повышение чувствительности и термостабильности. Чувствительность определяется как отношение величины выходного сигнала (напряжение разбаланса мостовой схемы под действием магнитного поля) $к$ величине магнитного поля на линейном участке передаточной характеристики. Были изготовлены магниторезистивные структуры с

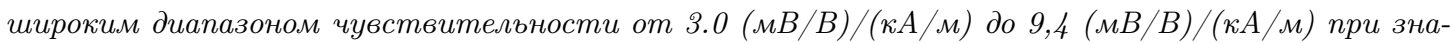
чении поля смещения $1 \mathrm{kA} / \mathrm{M}$. Установлено, что основное влияние на чувствительность сенсора оказывает ширина полос пермаллоя. Расстояние между полосами имеет существенно меньший эффект.

Ключевые слова: магниторезистивный сенсор, МЕМС, магнеторезистивность, магнеторезиcmop.
\end{abstract}

